\title{
Local institutional adaptation for sustainable water management under increasing climatic variability and change
}

\section{A case in the mid-Zambezi Valley, Zimbabwe}

\author{
Admire Mutsa Nyamwanza \\ Economic Performance and Development Unit, Human Sciences Research Council, \\ Cape Town, South Africa
}

Sustainable water management

Received 31 March 2017 Revised 11 July 2017 16 August 2017 12 October 2017 Accepted 16 October 2017

\begin{abstract}
Purpose - The study aims to explore institutional adaptation for sustainable water resources management at the local level in the context of increasing climate-related challenges in Zimbabwe using the case of a semiarid area in the mid-Zambezi Valley, north of the country.

Design/methodology/approach - Inspired by the critical institutionalism approach, the study uses qualitative methods (i.e. key informant interviews, semi-structured interviews, community workshops and documentary review) to understand the role of different formal and informal water-related institutions vis-àvis responding to climate-related challenges in the case study area, and how the identified institutions can improve their efforts in the context of national water and environmental policy and regulation frameworks. Thematic analysis was used for data analysis.

Findings - The study found that climatic challenges in the case study area, as in most of rural Africa, have raised the stakes in local water management with respect to regulating access to and balancing competing interests in, and demands for, water. It ultimately argues for the embracing of complexity thinking and flexibility in local water management as well as clear coordination of institutions across scales in the face of increasing climate-related challenges.
\end{abstract}

Originality/value - The study adds to case studies and evidence-based analyses focused on institutional alternatives for climate adaptation vis-à-vis water resources management in water-stressed rural African communities.

Keywords Sustainability, Climate variability, Institutional adaptation, Water management

Paper type Research paper

(C) Admire Mutsa Nyamwanza. Published by Emerald Publishing Limited. This article is published under the Creative Commons Attribution (CC BY 4.0) licence. Anyone may reproduce, distribute, translate and create derivative works of this article (for both commercial \& non-commercial purposes), subject to full attribution to the original publication and authors. The full terms of this licence may be seen at http://creativecommons.org/licences/by/4.0/legalcode

This paper is part of work undertaken by the author under the African Climate Change Fellowship Program Phase 3 (ACCFP III). The author would like thank the administrators of the program (i.e. the Institute of Resource Assessment and the International START) and the funders (i.e. the IDRC) for support. Gratitude is also extended to WaterNet Trust in Harare and the African Climate and Development Initiative at the University of Cape Town who were the author's respective host and home institutions during the Fellowship program.

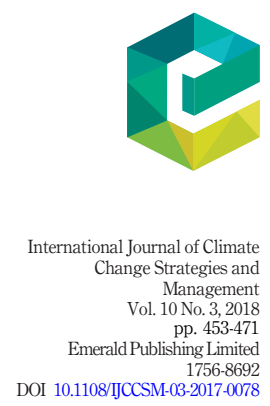




\section{IJCCSM 10,3}

\section{Introduction}

Increasing climatic variability and change has caused and is projected to trigger many challenges vis-à-vis availability of water, particularly in arid and semi-arid areas. This will, subsequently, place significant management demands on water-related institutions, especially with respect to regulating access for productive and domestic uses and the maintenance of vital ecosystems. As Sadoff and Muller (2009) write, the hard reality is that climate-related challenges will force many trade-offs, for example, around water regulation implementation at the local level. This will require adaptive, flexible and innovative institutions. Institutions are conceptualized in this paper in the mould of North (1990) as formal and informal rules and regulations through which people govern, organise and cooperate to achieve particular purposes. Institutions are critical, as they enable or hinder people's responses to climate-related challenges in various ways. Important functions that water-related institutions undertake, relevant for climate adaptation in local communities, include regulating access to resources and overseeing infrastructural maintenance, skills development and capacity building, influencing other decision-makers and institutions and information gathering and dissemination.

It is, therefore, critical to focus attention on the nature and structure of institutions governing access to and use of key resources such as water in the context of increasing climate-related challenges. This is important if adaptation processes and interventions are to succeed and help particularly the most vulnerable individuals, households and groups at the local level. It is in this context that this study explored institutions and options for institutional adaptation at the local level vis-à-vis sustainable water management in rural Zimbabwe using the case of Mbire District in the mid-Zambezi Valley area of Mashonaland Central Province. The term "institutional adaptation" is taken to mean modifications and alterations within institutions or its components to adjust to changes in the wider physical and social environment (after Adger, 2000). On the other hand, sustainable water management in this study alludes to:

Innovative investments for capacity extension in water access and use, ensuring efficient and equitable operation of existing water systems for optimal use, overseeing the continued maintenance and rehabilitation of water systems and modification in processes and demands towards reconciling social justice and environmental integrity concerns (Nyamwanza and Kujinga, 2017, pp. 695-696).

Sustainable water management under increasing climate-related challenges requires responsive and adaptive institutions, as water management primarily takes place within local and national institutional arrangements (Nyamwanza and Kujinga, 2017). The study essentially adds to evidence-based analyses on local institutional alternatives for climate adaptation vis-à-vis water management in water-stressed rural African communities.

The overriding question of interest was, what should local water-related institutions do to evolve and become more capable and effective in assisting local communities to deal with increasing climate-related challenges? Pursuant to this main question, the following four research questions were explored:

$R Q 1$. What are the formal and informal institutional arrangements that govern access to and use of water resources at the local level in the case study area?

RQ2. How are the institutions structured and what are the results of cross-scale institutional linkages and collaborations (if any), particularly with respect to assisting community members to effectively respond to the impacts of climaterelated challenges? 
RQ3. How have the different institutions facilitated particular types of adaptation strategies in the area and what have been the levels of success of their efforts over the years?

RQ4. What alternatives are there vis-à-vis sustainable water management and improving the institutions' efforts in adaptation processes in the area in the context of current national water and environmental policies and regulations?

The study was influenced by the critical institutionalism (CI) approach. CI is a body of thought that seeks to explore how institutions dynamically mediate relationships between people, natural resources and society (Cleaver and de Koning, 2015). It posits that institutions are dynamic and that they must not necessarily be designed and/or perpetuated for single specific purposes, but should be flexible and open enough towards integration with other working arrangement as conditions evolve (Hall et al., 2013; Cleaver and de Koning, 2015). To that end, the interplay of institutions is given particular attention in CI, and the idea of "institutional bricolage" is given prominence within the approach. Cleaver, 2012, p. 45) defines institutional bricolage as:

A process in which people consciously and non-consciously draw on existing social formulae (style of thinking, models of cause and effect, social norms and sanctioned social roles and relationships) to patch or piece together institutions in response to changing situations.

Institutional bricolage therefore involves mixing old and new arrangements to come up with more practical and useful institutional frameworks (Cleaver and de Koning, 2015). In the context of institutional adaptation for sustainable water management under increasing climate-related challenges, a promising direction for CI, as applied to this study, would be to draw on different available institutional actors, materials and resources, regardless of their original purposes, to come up with innovative and responsive institutional arrangements. Adapted configuration of rules, practices, norms and relationships are then attributed meaning and authority (Cleaver and de Koning, 2015).

The paper is divided into six sections. Following this introduction section is an exploration of the national water, environmental and climate context within which the study was undertaken, in Section 2. This includes a presentation of evidence of climate change in Zimbabwe in general and implications on water resources, and a discussion of current national policies and regulatory frameworks informing water, the environment and climate change. Section 3 is the methodology section, which includes contextual information on the case study area and methods used for data collection and analysis. Section 4 presents results from the fieldwork exercise and documentary review towards addressing the research questions. Section 5 then discusses alternatives for improving local water-related institutions' efforts in adaptation processes in the case study area. Lastly is the conclusion section.

\section{The national water, environmental and climate change context}

2.1 Evidence of increasing climate challenges and implications on water resources in Zimbabwe

According to Zimbabwe's National Climate Change Response Strategy document, the country's continental interior location means that it is predicted to warm more rapidly in the future than the global average (Government of Zimbabwe, 2015). Already, the Zimbabwe Meteorological Services has reported that daily minimum temperatures have risen by approximately $2.6^{\circ} \mathrm{C}$ over the past century, while daily maximum temperatures have risen by $2^{\circ} \mathrm{C}$ during the same period, with anecdotal evidence also pointing to wet seasons 
IJCCSM

10,3

progressively starting later (Brown et al., 2012; Davis and Hirji, 2014). Chagutah (2010) notes that by the end of the twentieth century, Zimbabwe had become warmer and drier than it was at the beginning, with annual mean temperatures having increased by about $0.4^{\circ} \mathrm{C}$ since 1900 and rainfall having declined by nearly 5 per cent across the country. Citing studies undertaken by the University of Zimbabwe's Department of Geography, Brown et al. (2012) note that there is a predicted warming of around $2^{\circ} \mathrm{C}$ by 2080 in Zimbabwe, with annual rainfall averages predicted to be between 5 per cent and 18 per cent less than the 1961-1990 average by the same year (Government of Zimbabwe, 2015). Furthermore, whilst Zimbabwe has experienced periodic floods and, on average, one to three droughts every five years largely due to changes in the phase of the El Nino Southern Oscillation (ENSO) phenomenon and periodic sea surface temperature changes, these are expected to increase in frequency and intensity due to global climate variability and change (Chagutah, 2010).

Owing to the noted climate dynamics, there is projected to be a severe strain on the country's surface and groundwater systems, and this will have a heavy effect on the demand for, and supply and quality of water in local communities. Already, there has been a decline in stream flow over the past 20 years in the country, although it is not clear that this decline is because of climatic changes (Government of Zimbabwe, 2015). What is more certain however is that due to increased warming, evaporation is predicted to increase by between 4 to 25 per cent in the river basins, and run-off projected to decline by up to 40 per cent. The Zambezi basin (within which the case study area is located), is projected to be the worst affected (Brown et al., 2012). Consequently, both rainfed and irrigated agriculture will face reduced yields.

It is also estimated that existing dams constructed for water supply and irrigation may become less reliable, and there is likely to be increased reliance on groundwater since, unlike surface water, it is shielded from evaporative losses (Government of Zimbabwe, 2015). Yet surface water contributes over 90 per cent of the country's water supply (Mtisi and Prowse, 2012), whilst the potential to fully utilise groundwater in Zimbabwe has not yet been realised mainly due to the unaffordability of the required technology (Brown et al., 2012). It is important at this point to note that Zimbabwe had developed an extensive water storage capacity prior to and after independence. This, however, went on to severely deteriorate in many areas post 2000 due to the serious economic and financial crises that engulfed the country between 2000 and 2009. For instance, dam construction and inspection, irrigation scheme establishment and maintenance and other major water projects either stalled or became redundant (Davis and Hirji, 2014).

\subsection{Environmental management in Zimbabwe}

Climate and water are part of the wider environmental system. It was therefore important to understand the general environmental policy framework in Zimbabwe so as to obtain a clear picture with respect to the national environmental management context within which local water-related institutions operate. Environmental management in Zimbabwe is primarily regulated by the Environmental Management Act of 2002. This Act provides the overall framework for the sustainable management of natural resources, including water, and protection of the environment. The Environmental Management Act is administered by the Environmental Management Agency (EMA), a statutory body in the Ministry of Environment, Climate and Water. Among its core principles, the Environmental Management Act states that all elements of the environment, e.g. water, climate, vegetation, air and soils are linked and interrelated and, therefore, environmental management must be integrated and the best practicable environmental management options pursued. It also states that environmental management must place people and their needs at the forefront of 
its concerns. Furthermore, it notes that sensitive, vulnerable and highly dynamic or stressed ecosystems require specific attention in management or planning procedures, especially when they are subject to significant human resource usage and development pressure (Section 4.2, Environmental Management Act). EMA has officials at both provincial and district levels who have a duty to assist local authorities in formulating by-laws which dovetail with national environmental policies as well as ensuring compliance to these laws.

Sustainable water management

\subsection{National climate change policy framework}

Zimbabwe has a fairly sound climate change policy framework. It has actively participated in international negotiations on climate change, having signed and ratified the United Nations Framework Convention on Climate Change (UNFCCC) in 1992 and acceded to the Kyoto Protocol in 2009. The country produced its Initial National Communication to the UNFCCC in 1998 and the Second National Communication in 2013. A National Climate Change Response Strategy (NCCRS), which provides a framework for a comprehensive and strategic approach on climate adaptation, mitigation, technology, financing, public education and awareness, was finalized in 2015. The NCCRS aims at bringing about an integrated response strategy across all sectors.

The main entity at the forefront of formulating and leading the implementation of climate change policy in Zimbabwe is the Department of Climate Change Management housed in the Ministry of Environment, Water and Climate. Its responsibilities include engaging with the UNFCCC and producing National Communications and coordinating specific national climate change projects between and across various ministries and organizations. Two Acts also implicitly deal with climate change issues in the country and these are:

(1) The Civil Protection Act of 1989 administered by the Ministry of Local Government, Public Works and National Housing. The Act provides for disaster management activities, thus including solutions to extreme weather events due to climate change and variability.

(2) The Meteorological Services Act of 1990 establishing the administration of meteorological services and providing for the carrying out of meteorological research and investigation, including the issuing of weather forecasts and climate projections.

\subsection{National water policy and regulation frameworks}

National water policy and regulation frameworks in Zimbabwe are primarily governed by two pieces of legislation - the Water Act and the Zimbabwe National Authority (ZINWA) Act - both promulgated in 1998. The country also has a National Water Policy document launched in 2012, which states its overall objective as assisting in the achievement of sustainable utilization of water resources (Government of Zimbabwe, 2012). The Water Act vests ownership of all water in the President rather than private land owners. It also provided for the establishment of catchment and sub-catchment areas (overseen by catchment councils [CCs] and sub-catchment councils [SCCs]). These catchment areas were drawn according to hydrological boundaries and they form the basis for water planning, issuing of water-use permits, establishing the rights and responsibilities of water users and assigning responsibility for dam safety (Davis and Hirji, 2014). To that end, seven catchment areas were established in the country. 
IJCCSM

10,3

The ZINWA Act established the Zimbabwe National Water Authority (ZINWA) - a parastatal whose functions vary depending on the level at which it is operating. At the national level, ZINWA advises the Minister responsible for water on formulation of national policies, water resources development and management and water pricing. At the local level, its roles include ensuring that $\mathrm{CC}$ and SCCs discharge their functions in accordance with the Water Act. Zimbabwe's national water policy and regulation frameworks are ultimately based on the underlying concept of "integrated water resources management" which emphasizes four main principles namely: management of water on the basis of hydrological boundaries, decentralization of water management, stakeholder participation and representation in water management processes and treatment of water as an economic good (Mtisi, 2011). Apart from the Water Act and the ZINWA Act, three other Acts also inform water resources management in (rural) Zimbabwe. These include:

(1) The discussed Environmental Management (EMA) Act of 2002 which provides the overall framework for the sustainable management of natural resources and protection of the environment (see Section 2.2).

(2) The Rural District Councils (RDC) Act of 1996 which empowers rural councils to formulate by-laws governing, among other aspects, natural resources within their jurisdiction.

(3) The Public Health Act of 2002 which, among other aspects, regulates issues around water quality monitoring, safe water supply and household sanitation.

There is also the Ministry of Transport, Communication and Infrastructural Development (MTCID) which maintains a small unit through the District Development Fund (DDF). The unit is responsible for providing technical guidance and expertise to RDCs in planning and supervising rural water, sanitation and hygiene and borehole drilling, as well as pump maintenance and rehabilitation (Government of Zimbabwe, 2012). The National Water Policy document of 2012 recognizes climate change and calls for the establishment of specific provisions for understanding the extent of the threat and specific actions for managing potential impacts (Davis and Hirji, 2014).

\section{Methodology}

3.1 Case study area

The area selected for case study (Mbire District) has 17 wards/local administrative geographical boundaries. This is a semi-arid remote area bordered by Zambia, Mozambique, Mashonaland West Province and other Mashonaland Central Districts of Guruve and Muzarabani (Figure 1). Mbire District is characterized by a dry, tropical climate with temperatures which can range up to $40^{\circ} \mathrm{C}$ in summer and low rainfalls averaging $450-650$ $\mathrm{mm}$ annually. From documentary analysis and interviews with key informants and community members, main weather and climate dynamics in the area have primarily been characterized by increasingly high air temperatures, increasing erratic rainfall patterns and increasing frequency in the occurrence of extreme weather events, particularly droughts and floods. This case study was selected based on the fact that the impacts of climate challenges are likely to be more severe in social and ecological contexts of arid and semi-arid regions. These are areas where livelihoods are often already stressed and additional adverse biophysical and social changes can be overwhelming (Agrawal, 2008). This makes the identification and understanding of viable adaptation solutions and alternatives in such contexts urgent. 


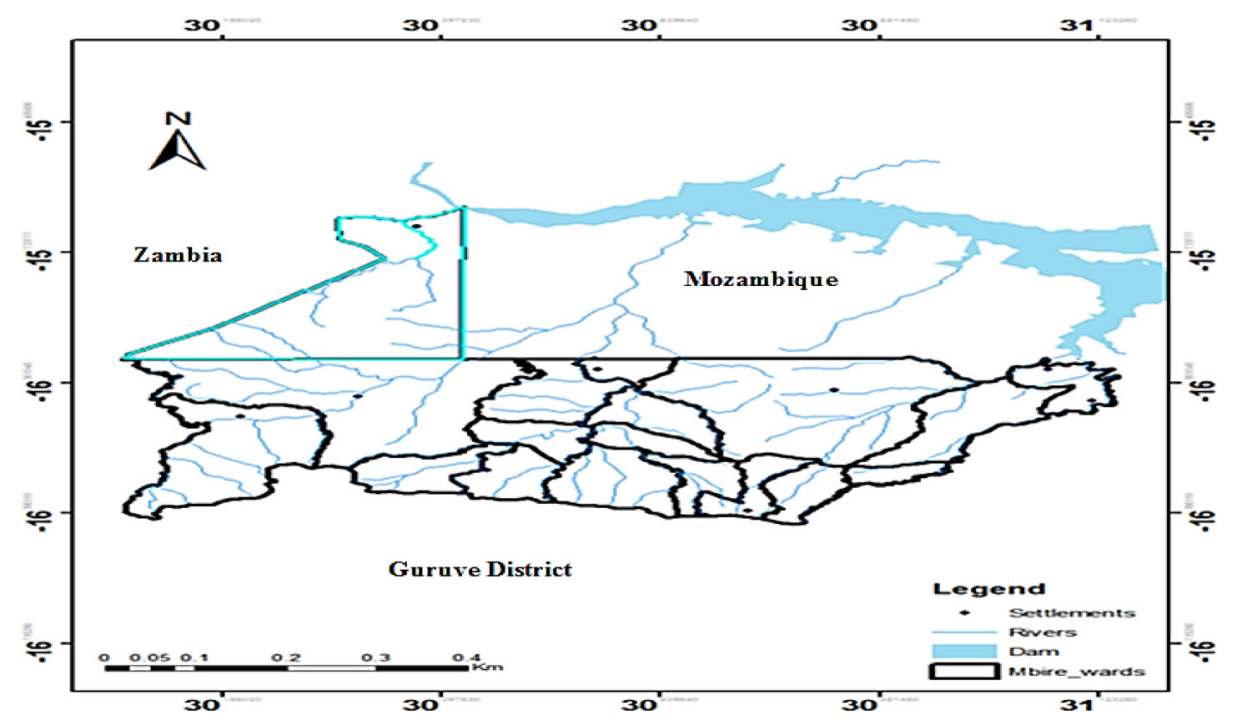

Sustainable water

management

\subsection{Methods}

Fieldwork for this study was undertaken in the period September-October 2015. The study used semi-structured interviews with community members, key informant interviews (KIIs), community workshops and documentary analysis. KIIs were conducted, firstly, at the national level, with officials from the Zimbabwe National Water Authority, Environmental Management Agency and the Department of Climate Change Management. Secondly, KIIs were conducted at the local level in Mbire District with selected officials involved in identified water-related institutions in the area (i.e. Mbire Rural District Council, Environmental Management Agency, Traditional Authority and Borehole Water Committees). Questions for national-level key informants revolved around the roles of their institutions in national climate change and/or water policy formulation, their views on the alignment of national water policies and regulations with climate dynamics in water-stressed rural communities in Zimbabwe and their roles and activities (if any) in the specific case study area of Mbire District. Questions for local-level key informants revolved around the role of their institutions in water management in the area, any changes/alterations and challenges and opportunities vis-à-vis their water management processes and practices owing to climate challenges in the area, and collaborations with other institutions.

In total, 34 semi-structured interviews and 3 community workshops were conducted with randomly selected adult respondents in the area. Questions in semi-structured interviews and community workshops included those around water resources and sources of livelihoods in the area, institutions involved in water management in the area (including the effectiveness of these institutions in the context of increasing climate challenges), adaptation strategies as facilitated and/or enabled by identified water-related institutions and respondents' views on how these institutions may improve their efforts. A documentary review of relevant published and unpublished materials was also used in exploring issues around the national water, environmental and climate change contexts in Zimbabwe. All data were analysed using thematic analysis method. 


\section{IJCCSM \\ 10,3}

460

\section{Results}

\subsection{Sources of livelihoods, water sources and their uses in Mbire District}

4.1.1 Sources of livelihoods in Mbire District. Understanding sources of livelihoods was important in establishing key productive uses of water in the area. Sources of livelihoods in the area revolve around agricultural activities - encompassing crop and livestock production as well as local casual agricultural work (in other villagers' fields for payment in cash or in kind). People are also involved in non-agricultural activities which include fishing (for both household consumption and commercial purposes), trading in goods (in small shops and flea markets) and remittances for a few households. Crop production involves two systems: the upland and the riverbank crop production systems. The upland crop production takes place in upland fields or minda yekunze in the Shona vernacular, averaging 2 to 5 ha per household. The upland fields consist of shallow sandy clay soils, and are used for dryland crop production involving mainly cotton, sorghum and groundnut farming. Riverbank crop production takes place in fields on the banks of major rivers, referred to as minda yekugova in the area, and averaging 0.5 to 2 ha per household.

Riverbank fields form the most arable lands in the area as they are characterised by rich alluvial fertile soils which store residual moisture from the rainy season into the dry season, thereby enabling villagers to conduct farming there the whole year round. Kinship and lineage are important factors in the ownership of riverbank fields as the fields are inherited and passed on from generation to generation. The majority owners of riverbank fields are autochthonous residents, with others gaining usufruct rights as mainly based on close neighbourhood, friendship or kinship. Major crops grown in riverbank fields include maize, green vegetables and tomatoes. All households interviewed were involved in both upland and riverbank crop production during the time of the research. Livestock production in the area includes cattle, goat, sheep, pig and poultry rearing, with cattle, goats and poultry forming the larger number of animals.

4.1.2 Sources of water in Mbire. The main sources of water in the area include rivers, seasonal streams, boreholes, protected and unprotected wells. Table I shows the main water sources for different uses and the importance of the different sources as ranked by respondents in semi-structured interviews according to reliability of the water source and frequency of use throughout the year.

\begin{tabular}{ll} 
Water use & Sources (ranked according to importance) \\
\hline Upland crop production & Rainfall \\
Riverbank crop production & Seasonal streams \\
Livestock watering & Rivers \\
& Rainfall \\
& Rivers \\
& Seasonal streams \\
Domestic use & Boreholes (during dry seasons) \\
& Unprotected wells (in dry seasons) \\
& Boreholes \\
& Protected and unprotected wells \\
& Seasonal streams \\
& Rivers
\end{tabular}

\section{Table I.}

Water sources and their uses in Mbire District 


\subsection{Climate-related challenges in Mbire District}

This section discusses climate-related challenges in Mbire District over the years and their impacts vis-à-vis water and livelihoods. Climate challenges and their impacts were understood through exploring unfavourable weather and climate dynamics in the area over the years, and how these dynamics have had an effect on general water availability for both agricultural and domestic purposes. Evidence from both primary fieldwork exercises and secondary data shows that the most serious climate challenges have manifested through increasing intra-seasonal dry spells, increasing drought cycles and floods.

4.2.1 Intra-seasonal dry spells. Respondents in community workshops and semistructured interviews pointed out that the frequency of dry spells during cropping seasons has increased over the years. These dry spells were noted as mainly occurring early in the season, particularly between October and December - coinciding with the germination stage when crops are most sensitive to moisture stress. A season was therefore said to be able to receive normal (or even increased) rainfall amounts; however, these intra-seasonal dry spells, coming at a time when crops are at a critical stage of growth, have many a time led to reduced quantity and quality of crop yields. Respondents also noted shifts in the onset of rains as well as seasons becoming shorter as other climate-related developments compounding the problem of intra-seasonal dry spells.

4.2.2 Increased drought cycles. Local-level key informants and community members during interviews stated that droughts were increasing in frequency in recent years. It was noted that droughts were now occurring on average every three years (unlike the five-year average which was usually experienced in the 1980s and 1990s). These droughts have led to total crop failure (especially in upland fields), drying up of rivers and boreholes and livestock deaths. A historical timeline exercise identifying serious drought years which have occurred in the area since 1980 carried out with community members during community workshops showed the following years as having been affected: 1982-1983, 1991-1992, 19941995, 2001-2002, 2003-2004, 2006-2007, 2008-2009 and 2012-2013. The trend clearly showed an increasing frequency in the occurrence of droughts. When asked on the general availability of water for both agricultural and domestic purposes over the preceding five years prior to the fieldwork, slightly over 60 per cent of respondents in semi-structured interviews noted that water for both agricultural and domestic purposes was generally becoming scarcer as opposed to being "enough" or "abundant" (Figure 2). The main reasons proffered for this were the drying up of streams, boreholes and wells owing to increasing drought cycles.

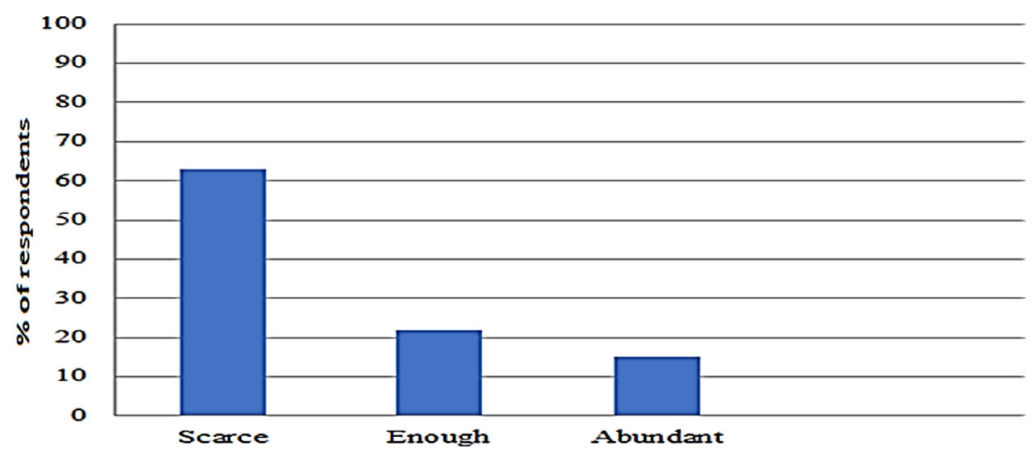

Figure 2.

Community members' perceptions on the general availability of water in Mbire District 


\section{IJCCSM 10,3}

462
4.2.3 Floods. Floods in Mbire have mainly occurred due to two factors:

(1) excessive local rains occurring mostly around January/February; and

(2) water release from Kariba Dam upstream and backflow from Cabora Bassa Dam in Mozambique further downstream.

The second factor arises from the fact that Mbire District is located downstream of Kariba Dam and upstream of Cabora Bassa Dam. From December to February, Kariba Dam levels usually rise higher than normal and water is released to avoid dam failure. This results in substantial increase in discharge into the Zambezi River and backflow pressure from Cabora Bassa Dam. Subsequently, major rivers in the district (i.e. Manyame, Mwanzamutanda, Kadzi and Musengezi) will not be able to discharge into the Zambezi River which results in water accumulating at the confluence of these rivers to the Zambezi River, leading to flooding in the Mbire District area. A discussion with the RDC CEO and with community members across different wards revealed that flood frequency has increased in the district in the past two decades, with the most recent being experienced in 2014.

\subsection{Water-related institutions in Mbire District: structure and roles}

This sub-section discusses the various water-related formal and informal institutional arrangements involved in water management in Mbire as identified by respondents including their current roles and evolving structures. The section responds to research objectives one and two and sets the building blocks for analysing how the identified institutions may adapt or be positively transformed towards assisting people in the area to effectively deal with climate challenges discussed in Section 4.2. It is noteworthy at this point that whilst, as discussed in Section 2, CCs and SCCs, as well as ZINWA, are (supposed to be) the key institutions with respect to water management as established by the Water Act and the ZINWA Act, these institutions are hardly known and/or acknowledged as active in water management in Mbire. Figure 3 shows the percentages of people (among the 34 interviewed across the district), who had and had no knowledge of (the existence of) CCs, SCCs and ZINWA in the area. Over 90 per cent of respondents had no knowledge of the responsibilities, operations and activities of CCs and SCCs in the area. On the other hand, whilst a significant number of respondents acknowledged that they had heard of ZINWA (especially in the media in relation to its activities in towns and cities), they were not aware of its responsibilities as a water authority in the area and had never interacted with an official from ZINWA.

Figure 3.

Knowledge of CCs, SCCs and ZINWA

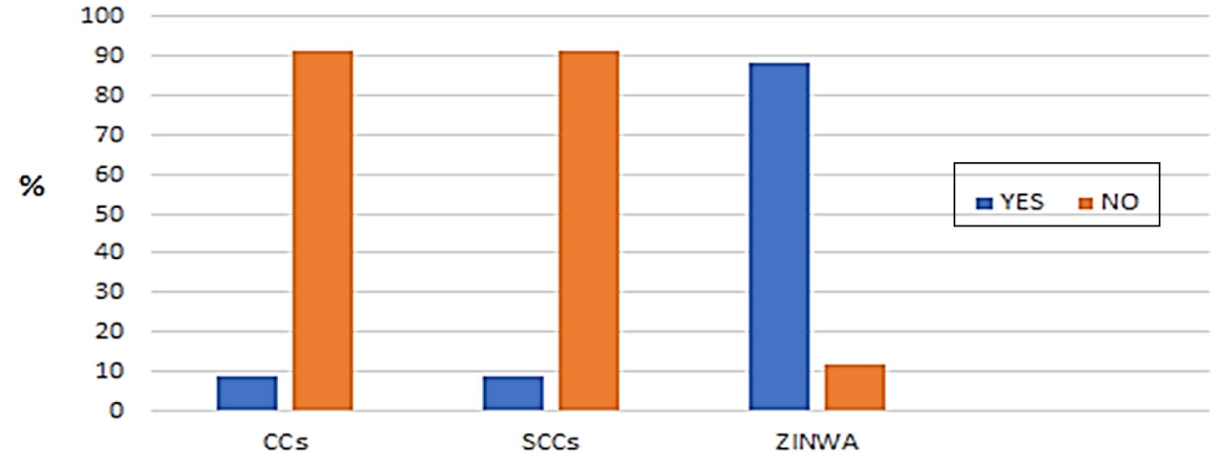


An agreed-upon fact therefore, even among interviewed key informants, was that though Mbire District does lie within Manyame catchment area, and within Lower Manyame and Angwa-Rukomechi sub-catchment areas, CCs, SCCs and ZINWA are not active with respect to water management in the area. This resonates with observations from other rural communities in the country (Kujinga, 2004; Twikirize, 2005). A ZINWA official in the capital Harare noted during an interview that communal areas such as Mbire have not had sustained water use for commercial purposes and have not had a stake in commercial water which is why these institutions are not active in these areas. He also noted that the lack of financial resources, especially between 2000 and 2009, crippled the operations of these institutions such that they failed to actively penetrate and establish functional structures covering such marginal areas as Mbire District. These institutions are therefore not included in discussions in this paper. Discussions in this section cover the following water-related institutions as identified in the area: The Rural District Council (RDC), the Environmental Management Authority (EMA), traditional authorities (TAs), the Ministry of Transport, Communication and Infrastructural Development's District Development Fund unit (MTCID's DDF) and Borehole Water Committees (BWC). Table II summarizes the various responsibilities of these water authorities vis-à-vis specific water resources in the area.

4.3.1 Rural District Council. The RDC was the institution mentioned by the highest number (over 80 per cent) of respondents when asked to identify water-related institutions in the area. According to the Mbire RDC Chief Executive Officer, the RDC's roles in water management in the area range from instituting by-laws regulating such water resources as rivers and streams, settling disputes and conflicts that may arise among water users, e.g. between upstream and downstream water users, to training other water-related institutions like borehole water committees in water-point management. He noted that the RDC was also the responsible authority overseeing the spearheading of major water investments planned for the area, particularly the construction and resuscitation of dams and irrigation schemes, as well coordinating

\begin{tabular}{|c|c|c|}
\hline Water authority & Specific water resource (s) managed & Responsibilities \\
\hline $\mathrm{RDC}$ & Rivers and streams & $\begin{array}{l}\text { instituting and enforcing by-laws, } \\
\text { solving disputes and conflicts that may } \\
\text { arise between and among users } \\
\text { training borehole committees on water- } \\
\text { point management }\end{array}$ \\
\hline EMA & Rivers and streams & $\begin{array}{l}\text { monitoring compliance to and enforcing } \\
\text { national regulations and local by-laws }\end{array}$ \\
\hline TAs & Rivers and streams & $\begin{array}{l}\text { instituting and enforcing regulations on use, } \\
\text { solving disputes and conflicts that may } \\
\text { arise between and among users }\end{array}$ \\
\hline MTCID's DDF unit & Boreholes & $\begin{array}{l}\text { drilling and ensuring maintenance and } \\
\text { rehabilitation }\end{array}$ \\
\hline BWCs & Boreholes & $\begin{array}{l}\text { instituting and enforcing regulations on use, } \\
\text { ensuring maintenance and rehabilitation, } \\
\text { solving disputes and conflicts that may } \\
\text { arise between and among users, } \\
\text { monitoring and guarding against water } \\
\text { theft }\end{array}$ \\
\hline
\end{tabular}

Sustainable water management

463

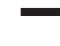


IJCCSM 10,3

responses to water-related extreme weather events such as droughts and floods. With these diverse roles, the RDC can therefore be said to be the main regulating authority of water resources in Mbire District. The RDC also collaborates with other formal and informal water-related institutions in the area vis-à-vis coming up with and enforcing water-related regulations in the area.

4.3.2 Environmental Management Authority. The EMA, as discussed earlier, derives its authority from the EMA Act (2002), and it was identified by respondents as also very visible in water-resources management in the area. According to the EMA Mbire District Officer, EMA's primary role, as derived from the EMA Act, relates to overseeing the general protection of the environment. This includes prevention of water pollution and proper utilization of commonly held resources as rivers and streams. The high visibility of EMA in Mbire District has mainly been due to the widespread engagement in riverbank farming in the area and contestations between villagers and authorities around this practice (which will be discussed in detail in the following sections). EMA officers work hand-in-glove with the $\mathrm{RDC}$ in monitoring compliance of and enforcing by-laws and other regulations that fall within their mandate.

4.3.3 Traditional authorities. TAs identified as active in the management of water resources in the area include chiefs, headmen, village-heads and spirit mediums. These were noted as having quite a huge influence on the utilization of rivers and streams in the area particularly with respect to instituting and enforcing regulations of use, as well as settling disputes and conflicts that may arise in the process of utilizing the resources. Chiefs are the heads in the line of traditional authority followed by headmen and lastly village heads. These traditional leaders work hand-in-glove with spirit mediums, known in the area as homwe dzavanasekuru or masvikiro. Spirit mediums are responsible primarily for communicating and relaying messages from the departed royal ancestors who are believed to be the real owners of the land or varidzi venzvimbo in vernacular. The departed royal ancestors are believed to be the providers of rain and fertility of the land and responsible for the general protection of people against various social ills. Because of that, spirit mediums are consulted in times of intense community vulnerabilities such as droughts and floods thus their views on access to and use of commonly held natural resources as rivers and streams are hugely respected.

4.3.4 The Ministry of Transport, Communication and Infrastructural Development's District Development Fund unit. As already noted earlier, the DDF maintains a small unit within the MTCID responsible for the provision of technical guidance and expertise to RDCs in planning and supervising water sanitation and hygiene, borehole drilling, pump maintenance and rehabilitation. In Mbire District, the DDF unit was identified as having drilled close to 70 per cent of boreholes in the area and following up on the maintenance of these boreholes especially in the first few years of the setting up of the boreholes.

4.3.5 Borehole Water Committees. All functioning boreholes in the district are run by specific committees. BWCs are normally elected annually, and are chosen from among villagers consistently using a particular borehole within a "reasonable" radius as subjectively judged by borehole users themselves. BWCs therefore may or may not overlap village boundaries depending on where the borehole is positioned. BWCs typically consist of a chairperson, a vice chair, a treasurer and two committee members. Their major responsibility is to ensure the proper usage and maintenance of their particular borehole. When a borehole breaks down, they mobilise for its repair (e.g. collecting money from users to fund repairs, and looking for people to repair the borehole). They are also responsible for the periodic collection of funds for the purchasing of lubrication oil needed to consistently apply on the boreholes for their effective and efficient functioning. Furthermore, they are 
involved in settling disputes and conflicts that may arise among borehole users. Whilst it is every user's responsibility to monitor that water from their borehole is not being stolen, the $\mathrm{BC}$ is the ultimate authority in ensuring that water from the borehole is not being stolen by unauthorised users.

Sustainable water management

\subsection{Water-related institutional efforts in responses to climate challenges in Mbire}

This section discusses how the various water-related institutions identified in Section 4.3 have initiated and/or facilitated particular types of responses and/or adaptation strategies vis-à-vis climate challenges discussed in Section 4.2. The discussion starts with responses and/or strategies as initiated and/or facilitated by formal institutions before discussing those undertaken by TAs. Levels of success of the institutions' endeavours as assessed by officials involved in the various institutions and by community members are also discussed.

4.4.1 Efforts by the RDC. The RDC has initiated and facilitated various efforts towards assisting communities in Mbire District to adequately respond to all the climate challenges discussed in Section 4.2. In relation to dealing with dry-spells and droughts in the area, firstly, the RDC has instituted by-laws over the years to ensure responsible use and preservation of water resources. Water-related by-laws instituted include:

- the prohibition of streambank cultivation;

- the prohibition of illegal gold panning activities; and

- the prohibition of farming in wetlands.

The RDC has also facilitated and supervised most government and non-governmental drought relief programmes in the area over the years. In addition, the RDC has also trained most borehole water committees across the district in water point management, and appraising community members on the water, sanitation and hygiene (WASH) concept. According the RDC CEO, the RDC has also pushed strongly for the rehabilitation and/or revival of major water infrastructure in the area such as dams and irrigation schemes most of which have become dysfunctional and obsolete over the years - although this has met little success.

In as far as floods are concerned, the RDC is the local coordinating authority on the standing committee which deals with floods in the area. This committee includes representatives from the Provincial Civil Protection and Planning Committee (PCPPC), local health officials and community based organizations (CBOs) and various NGOs. The RDC is therefore actively involved in the provision of early warning to communities, community preparedness, evacuation and immediate and long-term relief assistance. Interviews with the district administrators and selected councillors however revealed that the flood response team is not adequately capacitated particularly with respect to the provision of such critical resources as vehicles, training (e.g. in conducting flood risk assessments) and financing (e.g. to enable the purchasing of reliable communication equipment for communities at high risk in the area).

4.4.2 Efforts by EMA. As already discussed in Section 2, the main mandate of EMA revolves around the general protection of the environment. In Mbire District, its work in as far as water management is concerned has revolved around:

- educating residents through awareness campaigns and community workshops on the advantages and benefits of protecting water resources in a drought and floodprone area; and

- enforcing environment related national and local by-laws with the assistance of officers from the Zimbabwe Republic Police. 


\section{IJCCSM 10,3}

Interviews with villagers and discussions in community workshops, however, revealed that there is now clear animosity between EMA officials and local communities due to what residents described as the institution's "zealous" enforcement of the contentious national streambank cultivation regulation (which prohibits cultivation "within $30 \mathrm{~m}$ of the naturally defined banks of a public stream") (Government of Zimbabwe, 1991). The head of the local EMA office admitted as much when he noted that their officers had, many times, even been threatened with mysterious deaths if they dared continue their forceful push to stop riverbank farming during their routine visits to monitor the extend of siltation being caused by riverbank farming activities across different wards.

This (animosity) is in the context of the high importance attached to riverbank fields in the area in as far as all-year-round maize and vegetable farming is concerned (as discussed in Section 4.1). Whilst the EMA officer interviewed noted that they were doing fairly well vis-à-vis educating and conscientising people on the need to find other innovative and sustainable response strategies to droughts and dry-spells without resorting to extensive riverbank farming and illegal gold panning, he articulated two main challenges in the course of carrying out their duties. These included:

- the reluctance of other institutional players to forcefully push for compliance to natural resource by-laws in the area - apparently because of the fear of the previously mentioned death threats; and

- resource shortages.

On resource shortages, he noted that, for example, the local office only had four on-theground officers, and these officers are expected to monitor natural resource protection across all the 17 wards in the district. He also noted that they only had one aging motorbike for transport, and they have had to rely mostly on the RDC for transport to carry out their work in the area.

4.4.3 Efforts by the MTCID's DDF unit. As noted in Section 4.3, the DDF unit has been instrumental in drilling and maintaining boreholes across all the 17 wards in Mbire District over the years, with over 70 per cent of the boreholes in the district having been sunk by the unit. Boreholes in drought-prone areas as Mbire are critical as important sources of water for both people and livestock. The activities of this unit in Mbire have, however, stalled owing to lack of resources. DDF units were 80 per cent dependent on donor funding (cf. Kwangare et al., 2014), and when funding from most Western countries was suspended in the early 2000 s primarily over the chaotic and violent "fast-track" land reform programme in Zimbabwe, their activities were heavily affected. Most boreholes have thus become dysfunctional because of lack of proper maintenance, with the situation being compounded by periodic floods in the area - where the few functional boreholes are at risk of being flooded and contaminated each time floods occur. The borehole situation in the district has, therefore, generally become dire. In virtually all wards for example, with the exception of Ward 1 only, the maximum number of people per borehole far supersedes the recommended figure (of 250 persons or 25 families per borehole according to the Government's Water and Sanitation Master Plan). According to the RDC Projects Officer, the worst affected ward (Ward 11/Masoka ward) has over 2,000 persons per functioning borehole.

4.4.4 Efforts by BWCs. According to villagers in community workshops, BWCs have been quite helpful in keeping most boreholes running and functional, especially in the background of receding DDF unit activities as discussed, coupled with massive population increases and the subsequent pressure on boreholes. The various borehole rules set by these $\mathrm{BCs}$ have, for example, ensured responsible use, regular maintenance and timely repair of boreholes. This has led to some level of water security, particularly for domestic purposes 
over the years in the area. Respondents however noted that owing to contamination of most boreholes during periodic floods and low rainfalls and recurring droughts (and the subsequent lowering of the water table in most places) in the area, most boreholes had become dysfunctional, leaving most committees redundant and leading to their folding up.

4.4.5 Efforts by TAs. Efforts by TAs (i.e. chiefs, headmen, village heads and spirit mediums) towards initiating and/or facilitating responses to climate challenges vis-à-vis water management in Mbire District have revolved around:

- preservation of such community water resources as rivers and streams; and

- raising community concerns vis-à-vis water resources and livelihoods with other water-related institutions.

In relation to the first point, the traditional leadership (together with other water-related institutions) has instituted, supported and helped enforce certain regulations particularly related to the responsible use and preservation of rivers and streams. This includes the previously mentioned regulation prohibiting illegal gold panning in rivers, proper authorization for sinking unprotected wells in the area, as well as warning and punishing culprits caught breaking rules within their areas of jurisdiction. On the second point, the traditional leadership has been very instrumental in convincing other water institutional players, particularly the RDC, on the significance of local livelihoods dynamics, particularly around riverbank farming, especially in the context of increasing droughts and dry-spells in the area. This has led to the modification of the previously mentioned national streambank cultivation regulation - where the RDC agreed that people can be allowed to continue farming in the riverbanks unhindered provided they do not use ox-drawn ploughs or any other farming implement besides the hoe. Although this agreement is still to get a full buy-in from other water-related institutions in the area, particularly EMA, it has helped people to respond to the effects of droughts and dry-spells in the area.

\section{Discussion and analysis}

\subsection{Adapting local institutions towards sustainable water management under increasing climatic challenges in Mbire District}

From discussions in Section 4, it is clear that increasing climate challenges in Mbire District have resulted in the general scarcity of water in the area for all uses and increased floods and drought cycles. This has led to the redundancy of most boreholes and a heavily compromised upland farming system, resulting in increased reliance on riverbank farming. Climate challenges in Mbire have consequently raised the stakes in local water management vis-à-vis balancing competing interests in, and demands for, water. This section explores options and alternatives for improving the discussed water-related institutions' efforts in helping communities in the area to effectively respond to (the effects of) increasing climate challenges. Three main categories of efforts can be identified from the various initiatives discussed. In their efforts, local water-related institutions have been involved in one or all of the following initiatives:

- ensuring the preservation and responsible use of water resources through waterpoint regulation and by-law formulation and enforcement;

- coordinating local flood response and drought-relief programs; and

- continuously engaging central government on the revival of key water infrastructure in the area (e.g. collapsed irrigation schemes, dysfunctional boreholes and dams). 
IJCCSM 10,3

Two factors are raised as options towards adapting local institutions vis-à-vis improving their efforts towards sustainable water management. These (factors) form the discussions in the following subsections.

5.1.1 Embracing complexity thinking and flexibility in local water management. Complexity thinking in natural resources management relates to accepting unpredictability and uncertainty as part of dealing with people and situations, as well as acknowledging a multitude of perspectives in decision-making (Simonsen et al., 2014). Complexity thinking advocates for flexible process-based learning as an essential part of decision-making, recognition of context-specific dynamics and taking up an experimental approach to resource management (cf. Nyamwanza and Kujinga, 2017). It therefore negates from, for example, new institutionalism thinking of predictability and use of routine processes and principles, towards an active recognition of unique contextual political, natural and socio-economic processes in all aspects of resource management. As the CI school propounds, institutional actors and structures should have the latitude to fluidly adjust in addressing new challenges and situations. In the case of Mbire, local water-related institutions have to take up complexity thinking and flexibility in both the formulation of water-point regulations and by-laws and their enforcement. A case in point is that of riverbank farming. Mbire is a dry area, and with climate challenges discussed in Section 4.2 - particularly increasing drought cycles and intra-seasonal dry-spells - riverbank farming has become extremely important in sustaining livelihoods. It is interesting to note that whilst the RDC and the traditional leadership agreed on modifying the national regulation on streambank cultivation in line with local dynamics, residents have continued to face pressure from EMA to stop farming activities in the riverbanks completely. Whilst officials from both EMA and the RDC noted during key informant interviews that they do work hand-in-glove, it is clear that there has not been convergence in dealing with the riverbank farming issue in the area - which feeds into the next point discussed in the following subsection.

5.1.2 Clear coordination of institutions in water management. As shown in earlier discussions, the water institutional environment in Mbire is characterized by a plurality of organizations and actors, as well as multiple rules and procedures some of which are overlapping. An example is that of the RDC, EMA and the traditional leadership who all regulate the use of, and access to rivers and streams in one way or the other. As already discussed in the previous subsection, one consequence of this multiplicity of institutions in water management has been confusion in applying and enforcing certain regulations. In the context of dynamics resulting from increasing climate-related challenges however (such as a surge in riverbank farming in the case of Mbire), there is need for clear coordination and collaboration of institutions as part of institutional adaptation to shifts in water resource use. This will help institutions to approach water laws and regulations, as well as tackle water-related problems in a more efficient and coordinated manner. Mensah (2014) argues that, from a network governance perspective, coordination and collaboration enhance social and anticipatory learning and action which are vital in building and sustaining institutional resilience. Whilst bringing together a diversity of stakeholders with varying mandates is inherently complex, the advantage in the Mbire context is that institutions already strongly collaborate in flood response and drought relief (led by the RDC). The structural frameworks and foundational processes for coordination towards collaborative water management are therefore present. The existing frameworks and processes of coordination may therefore be adapted to deal with broad water issues 
along the institutional bricolage concept advanced in the CI approach. This will ultimately facilitate the creation of platforms for collaborative decision-making, bringing together divergent views vis-à-vis approach to issues, as well information sharing among institutional players in water management in the area.

Sustainable water management

\section{Conclusions}

A clear message from this paper for institutional policy and practice vis-à-vis responding to adverse climate dynamics is that institutional adaptation for sustainable water management in arid and semi-arid areas like Mbire can be pursued through institutions embracing complexity thinking and flexibility as well clearly coordinating in all aspects of water management. This will include taking up complexity thinking and clear coordination in demand management (e.g. in issues of water resource conservation and conflict resolution), supply management (e.g. involving issues of infrastructure maintenance and rehabilitation) and planning (e.g. around short- and long-term drought and flood responses). Political and technical support is, however, also critical for successful local institutional adaptation towards sustainable water management. For example, local authorities in water management should be given ample latitude to adapt national regulations to local dynamics. They should also be equipped with technical knowledge and the ability to educate communities on the implications of climate variability and change on water resources and sustainable water use. Improved knowledge of the nature and pace of climate change and its impacts will also aid institutions to take up the right mentality in dealing with climate change issues and identify viable response options.

The research implications of this study are that it clearly shows that there are opportunities for water management and climate adaptation research to jointly contribute knowledge towards improving the capacity of local institutions in managing water resources under increasing climate challenges. Locally derived insights as those coming out of this work hold value for illustrating and understanding better not only the contested nature of water management in the context of increasing climate challenges but also the conditions and factors critical for institutional adaptation towards effective and sustainable water management in specific contexts.

\section{References}

Adger, W.N. (2000), "Institutional adaptation to environmental risk under the transition in Vietnam", Annals of the Association of American Geographers, Vol. 90 No. 4, pp. 738-758.

Agrawal, A. (2008), The Role of Local Institutions in Adaptation to Climate Change, Social Development Department, The World Bank, Washington, DC.

Brown, D., Chanakira, R.R., Chatiza, K., Dhliwayo, M., Dodman, D., Masiiwa, M., Muchadenyika, D., Mugabe, P. and Zvigadza, S. (2012), "Climate change impacts, vulnerability and adaptation in Zimbabwe", IIED Working Paper No 3, International institute for Environment and Development, London, available at: pubs.iied.org/pdfs/10034IIED.pdf

Chagutah, T. (2010), Climate Change Vulnerability and Adaptation Preparedness in Southern Africa: Zimbabwe Country Report, Heinrich Boll Stiftung Southern Africa, Cape Town, available at: https://za.boell.org/sites/default/files/downloads/HBF_web_Zim_21_2.pdf

Cleaver, F. (2012), Development through Bricolage: Rethinking Institutions for Natural Resource Management, Routledge, London.

Cleaver, F. and de Koning, J. (2015), "Furthering critical institutionalism", International Journal of the Commons, Vol. 9 No. 1, pp. 1-18, available at: http://doi.org/10.18352/ijc.605 
IJCCSM

10,3

Davis, R. and Hirji, R. (2014), Climate Change and Water Resources Planning, Development and Management in Zimbabwe: An Issue Paper, The World Bank, Washington, DC.

Government of Zimbabwe (1991), Natural Resources Protection Regulation, Government of Zimbabwe, Harare.

Government of Zimbabwe (2002), Environmental Management Act, Government of Zimbabwe, Harare.

Government of Zimbabwe (2012), Zimbabwe National Water Policy, Ministry of Environment, Water and Climate, Harare.

Government of Zimbabwe (2015), Zimbabwe National Climate Change Response Strategy, Ministry of Environment, Water and Climate, Harare.

Hall, K., Cleaver, F., Franks, T. and Maganga, F. (2013), "Critical institutionalism: a synthesis and exploration of key themes”, Working Paper No 63, Kings College London, Environment, Politics and Development.

Intergovernmental Panel on Climate Change (IPCC) (1996), Climate Change 1995: Impacts, Adaptations and Mitigations: Contribution of Working Group II to the Second Assessment Report of the IPCC, Cambridge University Press, Cambridge, MA.

Kujinga, K. (2004), "The dynamics of stakeholder participation in water resources management in Zimbabwe: a case study of the agricultural sector", MSc thesis, University of the Western Cape.

Kwangare, J., Mayo, A. and Hoko, Z. (2014), "Sustainability of donor-funded rural water supply and sanitation projects in Mbire district, Zimbabwe", Physics and Chemistry of the Earth, Vols 76/78, pp. 134-139.

Mensah, K.O. (2014), "Linking precaution to adaptive co-management to adapt rural water resources to climate change in Ghana", $\mathrm{PhD}$ thesis, University of Guelph, Ontario.

Mtisi, S. (2011), "Water reforms during the crisis and beyond: Understanding policy and political challenges of reforming the water sector in Zimbabwe", ODI Working Paper No 333, Overseas Development Institute, London, available at: www.odi.org/sites/odi.org.uk/files/odi-assets/ publications-opinion-files/7241.pdf

Mtisi, S. and Prowse, M. (2012), Baseline Report on Climate Change and Development in Zimbabwe, Government of Zimbabwe, Harare.

North, D.C. (1990), Institutions, Institutional Change and Economic Performance, Cambridge University Press, Cambridge, MA.

Nyamwanza, A. and Kujinga, K. (2017), "Climate change, sustainable water management and institutional adaptation in rural Sub-Saharan Africa”, Environment, Development and Sustainability, Vol. 19 No. 2, pp. 693-706.

Sadoff, C. and Muller, M. (2009), "Water management, water security and climate change adaptation: Early impacts and essential responses”, Global Water Partnership Technical Committee (TEC), Stockholm, TEC Background Paper No 14.

Simonsen, S.H., Biggs, R., Schluter, M., Schoon, M., Bohensky, E., Cundill, G., Dakos, V., Daw, T., Kotschy, K., Leitch, A., Quinlan, A., Peterson, G. and Moberg, F. (2014), Applying Resilience Thinking: Seven Principles for Building Resilience in Social-Ecological Systems, Stockholm Resilience Centre, Stockholm.

Twikirize, D. (2005), "An assessment of traditional water management practices and their implications for improved water governance in the Limpopo Basin: a case of the Sibasa Dam in Mzingwane catchment, Zimbabwe", MSc Thesis, University of Zimbabwe, Harare.

\section{Further reading}

Alvera, P. (2013), "The role of indigenous knowledge systems in coping with food security and climate challenges in Mbire district, Zimbabwe", MSc thesis, University of Zimbabwe, Harare. 
Mupangwa, J.F., Nyabadza, T., Mberengwa, I. and Chaipa, I. (2006), "Problem animal control strategies in human-elephant conflict areas of Dande Communal Lands, Zimbabwe: a study in sustainability", Journal of Sustainable Development, Vol. 8 No. 1, pp. 53-69.

Sustainable water management

\section{About the author}

Admire Mutsa Nyamwanza is a researcher with the Human Sciences Research Council (HSRC), Economic Performance and Development (EPD) Unit, based in Cape Town, South Africa. His main research interests are in the areas of climate change adaptation, livelihoods, resilience and social change in developing countries. Admire Mutsa Nyamwanza can be contacted at: anyamwanza@ gmail.com

For instructions on how to order reprints of this article, please visit our website: 